\title{
An efficient catalyzed Green synthesis of substituted coumarins using Potassium dihydrogen phosphate Catalyst and studies their Anti-microbial activities.
}

\author{
Anna R. Anthony ${ }^{1,}$ Abhay Choudhary ${ }^{2,}$ ShrikantGajbhiye ${ }^{2}$ \\ Department of Chemistry Maharshi Dayanand College-Parel ,Mumbai -12, India. \\ Director, Haffkine InstituteParel; Mumbai-12 \\ Department of bacteriology, Haffkine Institute Parel, Mumbai-12
}

\begin{abstract}
The Coumarine heterocyclic ring is common feature of various bioactive compounds such as calanolides, lipid-lowering agents. The Chemists all over the globe are motivated not only for the environmentally benign synthesis of new products but also to develop green synthesis for existing chemicals. Coumarins, the most important classes of fluorescent molecules constitute important structural features present in a number of bioactive natural products. Recent studies have been revealed that coumarin and the derivatives exhibit several other medicinal applications such as anti-coagulants, antifungal, insecticidal, hypnoticsphytoalexins, HIV protease \& inhibitors. Coumarins act as in intermediate for the synthesis of various biologically active molecule such as coumarones, and fluorocoumarins. Thus the synthesis of coumarins is of continuing interest.Potassium dihydrogen phosphate a commercially available environmentally benign catalyst non-toxic widely used for the synthesis of the substituted coumarin. The scope of this catalyst has not been fully explored, but can be used as buffer, neutralizing agent. Owing to the numerous advantages associated with cheap and non-hazardous catalyst, and also realizing $g$ the importance of coumarin herein we would like to focus the eco-friendly method for his synthesis of derivatives of coumarin using cheaper and commercially available acid catalysts Potassium dihydrogen phosphate and also by the Knoevenagel condensation under microwave irradiation. The synthesized coumarin derivatives were screened in Vitro anti-microbial efficacy testing. In vitro anti-microbial efficacy testing was carried out by broth dilution method by broth dilution method as mentioned in "Pharmaceutical Microbiology". For anti-bacterial activity, MullerHintonmedium was used as the nutrient media. Test bacterial species used are Escherichia coli ,(ATCC 10148), Staphylococcus aureus(NCTC 3750), Pseudomonas aeruginosa (Fisher'Immunotype IV), test fungi species used are Aspergilliusniger(ATCC 16404) and Candida albicans (ATCC 10231) in different concentrations starting from 25ppm. All the coumarin derivatives are active against the test bacteria and fungai in different concentrations. This paper focuses is to develop environment friendly reactions, simple, highly efficient and high yielding protocol for the synthesis of coumarin derivatives using Potassium dihydrogen phosphate as a catalyst.Even though a number of modified methods have been reported, but many of them suffer from drawbacks such as unsatisfactory yields, longer reaction time, and corrosive reagents. Thus the development of an efficient and versatile method to synthesis of coumarin derivatives is an active ongoing research and there is a scope further improvement towards milder reaction condition and yield. This methodology offers significant improvements for the synthesis of derivatives of coumarins with regard to yield of products, simplicity in operation and green aspects by avoiding toxic conventional catalysts and solvents. Therefore owing the importance of Potassium dihydrogen phosphate a facile catalyst used for the green synthesis of new derivatives of coumarin .
\end{abstract}

Key words: Potassium dihydrogen phosphate, microwave irradiation, anti-microbial,

\section{Introduction}

Coumarins and their derivatives are very important organic compounds; they are biologically active and widely occur in nature ${ }^{1}$. They are the structural unit of several natural products ${ }^{2}$. Their applications range from pharmaceuticals ${ }^{3}$, optical brighteners ${ }^{4}$, and laser dyes ${ }^{5}$. Also, coumarins and functionalized coumarins have shown activity as antimicrobials and chemotherapeutics ${ }^{6}$. Some coumarin derivatives have been widely used as an important chemical in perfume, cosmetic as well as pharmaceutical industrial preparation.. The coumarin heterocyclic ring is a common feature of various bioactive compounds such as Calanolides ${ }^{7}$, lipid lowering agents $^{8}$. Recent studies have been revealed that coumarin and the derivatives exhibit several other medicinal applications $^{9}$ such as anticoagulants, antifungal, insecticidal, hypnoticsphytoalexins, HIV protease \& inhibitors ${ }^{10}$. Coumarins act as in intermediate for the synthesis of various biologically active molecule such as coumarones, and fluorocoumarins. These properties have made coumarins interesting targets for organic chemists. Thus the synthesis of coumarins is of continuing interest. 
Some of the recent methods utilize several heterogenous as well as transition, metal catalyses ${ }^{11}$, solid phase synthesis ${ }^{12}$ and ionic liquids ${ }^{13}$. Most of the procedures from harsh reaction conditions (such as the use of stoichiometric amount of minerals, Lewis acids or toxic reagents, often under high temperatures and with longer reactions times), poor substituents tolerance and low yields ${ }^{14}$, Thus, it is clearly evident that development of new and flexible protocols is required.

On the other hand, in recent years, the concept of speeding up synthetic transformations by microwave activation has created a lot of interest in organic synthesis ${ }^{15}$, The coupling of microwave heating with solid phase catalysts in solvent-free conditions catalysis chemical processes with special attributes such as enhanced reaction rate, ease of work-up and high yields .

Potassium dihydrogenphosphate is another heterogeneous, commercially available environmentally benign, non-toxic acid catalyst, also used for the synthesis of the substituted coumarin. The commercially available catalyst Potassium dihydrogenphosphate having $\mathrm{pH}$ 4.2-4.7 is used as a catalyst but its scope of this catalyst has not been fully explored. It can be used as buffer, neutralizing agent ${ }^{20 \mathrm{~g}}$, Sequestrate, yeast food, and also as an efficient heterogeneous acid catalyst. Owing to the numerous advantages associated with cheap and non-hazardous catalyst, and also realizing the importance of coumarin , we would like to focus the eco -friendly method for his synthesis of derivatives of coumarin under solvent free and microwave irradiation technique using cheaper and commercially available catalyst Potassium dihydrogen phosphate .

\section{Experimental}

General Experimental Procedure for ( Scheme-1-A )A mixture of 2-hydroxyaldehyde(1) (100 $\mathrm{mmol})$, carbonyl compound (2) $(110 \mathrm{mmol})$, and piperidine $(0.20 \mathrm{~g}, 2.4 \mathrm{mmol})$ was irradiated and heated in a simple domestic microwave $800 \mathrm{Wfor} 4$ to 8 minutes. At the end of exposure to microwave, the reaction mixture was cooled to room temperature, and the crude product was recrystallized from an appropriate solvent. The compounds synthesised under this method labelled as $3(\mathrm{~h}-\mathrm{j})$ shown in Table.1. The reactions (i.e., the synthesis of Coumarins) were usually completed within 4-8 min. and gave improvement yield over conventional method in a shorter time. Moreover, the work-up procedure is simply reduced to the recrystallization of product from an appropriate solvent. The results from the experiments are shown in Table-2.The reactions were carried out under atmospheric pressure in an open vessel adapted to National $800 \mathrm{~W}$ microwave, power High. The compound $3(\mathrm{~h}-\mathrm{j})$ were analysed by, IR, NMR and gave satisfactory results in comparison with authentic samples. The melting points are in good agreement with literature data (Table -2\&3)

\section{Scheme-1-A}

I) Synthesis of coumarin derivatives by Knoevenagel condensation under microwave irradiation.

1) Condensation of 5-methoxy 2-hydroxy benzaldehyde with dimethyl malonate, in the presence of piperidine leads to the synthesis of derivatives of coumarin by solvent free reaction under microwave irradiation.(Figure-1)

2) Condensation of 5-nitro 2-hydroxy benzaldehyde with dimethyl malonate, in the presence of piperidine leads to the synthesis of derivatives of coumarin by a solvent free reaction under microwave irradiation. (Figure-1)

3) Condensation of 5-bromo 2-hydroxy benzaldehyde with dimethyl malonate, $e$ in the presence of piperidine leads to the synthesis of derivatives of coumarin by a solvent free reaction under microwave irradiation. (Figure1) Scheme 1-A\&Table-1<smiles>[R]CC(=O)O[Na]</smiles>

1

\section{Scheme 1-A}

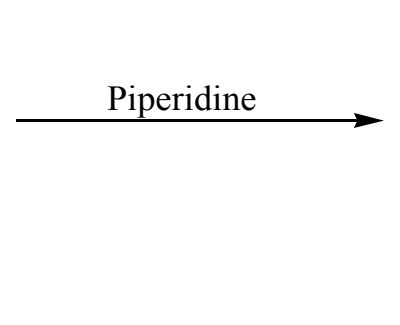

2<smiles>[R]c1cc2cc([R])c(=O)oc2c([R])c1[R]</smiles>

$3(\mathrm{~h}-\mathrm{j})$

Figure-1: Synthesis of Coumarin derivatives by Knoevenagel condensation under microwave irradiation in presence of piperidine Scheme 1-A \&using Potassium dihydrogen phosphate as catalyst.( Refer Table 1)

Table-1

\begin{tabular}{|c|c|c|c|c|c|}
\hline Sr.No. & Compound name & $\mathrm{R}^{1}$ & $\mathrm{R}^{2}$ & $\mathrm{R}^{3}$ & $\mathrm{R}^{4}$ \\
\hline 1 & $3 \mathrm{~h}$ & $\mathrm{H}$ & $\mathrm{H}$ & $-\mathrm{OMe}$ & $\mathrm{COOMe}$ \\
\hline 2 & $3 \mathrm{i}$ & $\mathrm{H}$ & $\mathrm{H}$ & $-\mathrm{NO}_{2}$ & $\mathrm{COOMe}$ \\
\hline 3 & $3 \mathrm{j}$ & $\mathrm{H}$ & $\mathrm{H}$ & $-\mathrm{Br}$ & $\mathrm{COOMe}$ \\
\hline
\end{tabular}


Table-2

\begin{tabular}{|l|l|l|l|l|}
\hline Sr.No. & $\begin{array}{l}\text { Compound } \\
\text { labelled as }\end{array}$ & Compounds name & $\begin{array}{l}\text { Melting point } \\
{ }^{\circ} \mathrm{C}\end{array}$ & $\begin{array}{l}\text { Yield } \\
\%\end{array}$ \\
\hline 8 & $3 \mathrm{~h}$ & 6-bromo-1-chromen-2-one 3-methyl carboxylate & 104 & 89 \\
\hline 9 & $3 \mathrm{i}$ & 6-nitro-1 -chromen-2-one3-3-methyl carboxylate & 182 & 180 \\
\hline 10 & $3 \mathrm{j}$ & 6-bromo1-chromen-2-one 3-methyl carboxylate & 175 & 65 \\
\hline
\end{tabular}

Table-3

\begin{tabular}{|l|c|l|l|}
\hline Sr.No & $\begin{array}{l}\text { Compoud } \\
\text { Name }\end{array}$ & IR(KBr) v́ $\mathrm{cm}^{-1}$ & ${ }^{1} \mathrm{HNMR}: \delta(\mathrm{ppm})$ \\
\hline 8 & $3 \mathrm{~h}$ & $1260,1175,1220$, & $3.91(\mathrm{~s}, 3 \mathrm{H}) 2,65(\mathrm{~s}, 3 \mathrm{H}) 8.65(\mathrm{~s}, 1 \mathrm{H})$, \\
& & $1720,3070,1590$ & $7.50(\mathrm{~s}, 1 \mathrm{H}) 7.38(\mathrm{~d}, 1 \mathrm{H}) 7.35(\mathrm{~d}, 1 \mathrm{H})$ \\
\hline 9 & $3 \mathrm{i}$ & $1190,3020,1172$, & $8.5(\mathrm{~s}, 1 \mathrm{H}), 7.42(\mathrm{~s}, 1 \mathrm{H}) 2.68(\mathrm{~s}, 3 \mathrm{H}) 7.8(\mathrm{~m}, 2 \mathrm{H})$ \\
& & $1590,1720,1190$ & \\
\hline 10 & $3 \mathrm{j}$ & $630,1350,1200$, & $2.5(\mathrm{~s}, 3 \mathrm{H}) 8.55(\mathrm{~s}, 1 \mathrm{H}) 7.45(\mathrm{~d}, 1 \mathrm{H}) 7.53(\mathrm{~d}, 1 \mathrm{H}) 7.60(\mathrm{~s}, 1 \mathrm{H})$ \\
& & $1720,3070,1590$ & \\
\hline
\end{tabular}

\section{General Experimental Procedure for (Scheme- 1-B)}

A mixture of compound $1(1 \mathrm{mmol})$ and compound $2(1 \mathrm{mmol})$ and potassium dihydrogenphosphate ( $20 \mathrm{~mol} \%)$ in ethanol $(10 \mathrm{~cm} 3)$ was stirred at room temperature for the one hour. The reaction mixture was neutralized using ammonium chloride solution and extracted with ether .ether layer was dried with sodium sulphate and evaporated to yield corresponding derivatives of coumarine.

\section{Scheme- 1-B}

1) Condensation of 5-methoxy 2-hydroxy benzaldehyde with dimethyl malonate, ethyl acetoacetate, ethyl benzoyl acetate and ethyl cyanoacetate in the presence of Potassium dihydrogenphosphate and catalyst leads to the synthesis of derivatives of coumarins.(Figure-2)

2) Condensation of 5-nitro 2-hydroxy benzaldehyde with dimethyl malonate, ethyl acetoacetate, and ethyl cyanoacetate in the presence of Potassium dihydrogen phosphate catalyst leads to the synthesis of derivatives of Coumarins. .(Figure-2)

3) Condensation of 5-bromo 2-hydroxy benzaldehyde with dimethyl malonate, ethyl acetoacetate, and ethyl cyanoacetate in the presence of Potassium dihydrogenphosphate catalyst leads to the synthesis of derivatives of coumarins.(Figure-2)

Scheme- 1-B<smiles>[R]C[C+]OC=O</smiles>

2<smiles>[R]c1cc2cc([R])c(=O)oc2c([R])c1[R]</smiles>

$3(\mathrm{~h}-\mathrm{j})$

Figure-2 -Synthesis of derivatives of Coumarin using Potassium dihydrogen phosphate as catalyst.( Refer Table 1)

\section{In Vitro Anti microbial Assay:}

\section{Pharmacology Analysis:}

The synthesized coumarin derivatives were screened in Vitro anti-microbial efficacy testing. In vitro anti-microbial efficacy testing was carried out by broth dilution method by broth dilution methods asmentioned in "Pharmaceutical Microbiology" . For anti-bacterial activity, Muller Hinton broth was used as the nutrient media. Test bacterial species used are Escherichia coli ,(ATCC 10148), Staphylococcus aureus(NCTC 3750), Pseudomonas aeruginosa (Fisher'Immunotype IV), test fungi species used are Aspergilliusniger(ATCC 16404) and Candida albicans (ATCC 10231) in different concentrations starting from 25ppm. All the coumarin derivatives are active against the test bacteria and fungai in different concentrations. The four different concentrations of the samples $25 \mathrm{ppm}, 50 \mathrm{ppm}, 100 \mathrm{ppm}, \& 150 \mathrm{ppmper}$ ml.were prepared and taken in Muller Hinton broth separately in sterile test tube and to each individual test tube $0.1 \mathrm{~cm}^{3}$ of above mentioned bacterial suspension was added (having approximately1.0 x $106 * \mathrm{CFU})$. These tubes were then kept for incubation at $37^{\circ} \mathrm{C}$ for 48 hours. To check the growth if any. 


\begin{tabular}{|c|c|c|c|c|c|c|}
\hline \multirow{3}{*}{$\begin{array}{c}\text { Sr.N } \\
\mathbf{o}\end{array}$} & \multicolumn{2}{|c|}{ Compound Name $3 \mathrm{~h}$} & \multicolumn{4}{|l|}{ Table-4 } \\
\hline & \multirow[b]{2}{*}{ Test bacterial species } & \multirow{2}{*}{$\begin{array}{l}\begin{array}{l}\text { Standard } \\
\text { reference sample }\end{array} \\
\text { Ampicillin/fluco } \\
\text { nazole (MIC) } \\
(\mathrm{ppm})\end{array}$} & \multicolumn{4}{|c|}{$\begin{array}{l}\text { Inhibition } \backslash \text { Viability of the test bacterial species after } 48 \\
\text { hours of incubation in the concentration of }\end{array}$} \\
\hline & & & $50 \mathrm{ppm}$ & $100 \mathrm{ppm}$ & $150 \mathrm{ppm}$ & $200 \mathrm{ppm}$ \\
\hline 1 & $\begin{array}{l}\text { Pseudomonas Aeruginosa } \\
\text { (Fisher's immunotype-IV) }\end{array}$ & 150 & $\mathrm{~V}$ & $\mathrm{~V}$ & $\mathrm{~V}$ & $* * \mathrm{~N}$ \\
\hline 2 & $\begin{array}{c}\text { Escherichia coli ,(ATCC } \\
\text { 10148), } \\
\end{array}$ & 100 & $\mathrm{~V}$ & $\mathrm{~V}$ & $\mathrm{~V}$ & $\mathrm{~N}$ \\
\hline 3 & $\begin{array}{c}\text { Staphylococcus aureus(NCTC } \\
3750) \text {, }\end{array}$ & 100 & $\mathrm{~V}$ & V & $\mathrm{V}$ & $\mathrm{N}$ \\
\hline 4 & $\begin{array}{c}\text { Aspergillius } \\
\text { Niger(ATCC 16404) }\end{array}$ & 150 & $\mathrm{~V}$ & $\mathrm{~V}$ & $\mathrm{~V}$ & $\mathrm{~N}$ \\
\hline 5 & $\begin{array}{c}\text { Candida albicans (ATCC } \\
10231 \text { ) }\end{array}$ & 100 & $\mathrm{~V}$ & V & $\mathrm{V}$ & $\mathrm{N}$ \\
\hline
\end{tabular}

\section{*CFU $=$ Colony formin}

$* * \mathbf{N}=$ No growth or bacteria was killed / inactivated

$\mathbf{M I C}=$ minimum inhibitory concentration expressed in ppm (parts per million in this contest)

Compound labeled as' 3h,' kills /inactivates the test organism Escherichia coli (ATCC 10148), Staphylococcus aureus(NCTC 3750), Pseudomonas aeruginosa (Fisher'Immunotype IV), test fungai species used are Aspergillius Niger(ATCC 16404) and Candida albicans (ATCC 10231) in the concentration of 200 $\mathrm{ppm}$, In other words the compound ' $3 \mathrm{~h}$ ' has shown the anti-bacterial/antifungal activities in the concentration of $200 \mathrm{ppm}$, against the above mentioned test bacterial/fungal species. Whereas Standard reference sample ampicillin/fluconazole (MIC) at 100ppm in the same condition against Escherichia coli, (ATCC 10148), and Staphylococcus aureus(NCTC 3750), but against Pseudomonas aeruginosa is150ppm. Standard reference sample fluconazole shows MIC at 100ppm against Candida albicans (ATCC 10231) but 150 ppm against Aspergillius Niger(ATCC 16404).

Compound Name 3i

Table-5

\begin{tabular}{|c|c|c|c|c|c|c|}
\hline \multirow[b]{2}{*}{$\begin{array}{c}\text { Sr.N } \\
\mathbf{0}\end{array}$} & \multirow[b]{2}{*}{ Test bacterial species } & \multirow{2}{*}{$\begin{array}{l}\text { Standard } \\
\text { reference sample } \\
\text { Ampicillin/fluco } \\
\text { nazole (MIC) } \\
(\mathrm{ppm})\end{array}$} & \multicolumn{4}{|c|}{$\begin{array}{l}\text { Inhibition Viability of the test bacterial species after } 48 \\
\text { hours of incubation in the concentration of }\end{array}$} \\
\hline & & & $25 \mathrm{ppm}$ & $50 \mathrm{ppm}$ & $100 \mathrm{ppm}$ & $150 \mathrm{ppm}$ \\
\hline 1 & $\begin{array}{l}\text { Pseudomonas Aeruginosa } \\
\text { (Fisher's immunotype-IV) }\end{array}$ & 150 & $\mathrm{~V}$ & V & $\mathrm{V}$ & $* * \mathrm{~N}$ \\
\hline 2 & $\begin{array}{c}\text { Escherichia coli ,(ATCC } \\
10148),\end{array}$ & 100 & V & V & V & $\mathrm{N}$ \\
\hline 3 & $\begin{array}{c}\text { Staphylococcus aureus(NCTC } \\
3750) \text {, }\end{array}$ & 100 & $\mathrm{~V}$ & V & $\mathrm{V}$ & $\mathrm{N}$ \\
\hline 4 & $\begin{array}{c}\text { Aspergillius } \\
\text { Niger(ATCC 16404) }\end{array}$ & 150 & $\mathrm{~V}$ & V & $\mathrm{V}$ & $\mathrm{N}$ \\
\hline 5 & $\begin{array}{c}\text { Candida albicans (ATCC } \\
10231) \\
\end{array}$ & 100 & $\mathrm{~V}$ & V & $\mathrm{V}$ & $\mathrm{N}$ \\
\hline
\end{tabular}

\section{$* \mathrm{CFU}=$ Colony formin}

\section{$* * \mathbf{N}=$ No growth or bacteria was killed / inactivated}

$\mathbf{M I C}=$ minimum inhibitory concentration expressed in ppm (parts per million in this contest)

Compound labeled as' 3i,' kills /inactivates the test organism Escherichia coli (ATCC 10148), Staphylococcus aureus(NCTC 3750), Pseudomonas aeruginosa (Fisher'Immunotype IV), test fungai species used are Aspergillius niger(ATCC 16404) and Candida albicans (ATCC 10231) in the concentration of 150 ppm, In other words the compound $3 i$ has shown the anti-bacterial/antifungal activities in the concentration of $150 \mathrm{ppm}$, against the above mentioned test bacterial/fungal species . Whereas Standard reference sample ampicillin/fluconazole (MIC) at 100ppm in the same condition against Escherichia coli ,(ATCC 10148), and Staphylococcus aureus(NCTC 3750), but against Pseudomonas aeruginosa is150ppm. Standard reference sample fluconazole shows MIC at 100ppm against Candida albicans (ATCC 10231) but 150 ppm against Aspergillius niger(ATCC 16404) . 


\begin{tabular}{|c|c|c|c|c|c|c|}
\hline \multirow[b]{3}{*}{$\begin{array}{c}\text { Sr.N } \\
\mathbf{0}\end{array}$} & \multicolumn{6}{|c|}{ Compound Name $\mathbf{3 j}$} \\
\hline & \multirow[b]{2}{*}{ Test bacterial species } & \multirow{2}{*}{$\begin{array}{l}\text { Standard } \\
\text { reference sample } \\
\text { Ampicillin/fluco } \\
\text { nazole (MIC) } \\
\text { (ppm) }\end{array}$} & \multicolumn{4}{|c|}{$\begin{array}{l}\text { Inhibition } \backslash \text { Viability of the test bacterial species after } 48 \text { hours } \\
\text { of incubation in the concentration of }\end{array}$} \\
\hline & & & $25 \mathrm{ppm}$ & $50 \mathrm{ppm}$ & $100 \mathrm{ppm}$ & $150 \mathrm{ppm}$ \\
\hline 1 & $\begin{array}{l}\text { Pseudomonas Aeruginosa } \\
\text { (Fisher's immunotype-IV) }\end{array}$ & 150 & $\mathrm{~V}$ & $\mathrm{~V}$ & $* * \mathrm{~N}$ & $\mathrm{~N}$ \\
\hline 2 & $\begin{array}{c}\text { Escherichia coli ,(ATCC } \\
10148),\end{array}$ & 100 & $\mathrm{~V}$ & $\mathrm{~V}$ & $\mathrm{~N}$ & $\mathrm{~N}$ \\
\hline 3 & $\begin{array}{l}\text { Staphylococcus aureus(NCTC } \\
3750) \text {, }\end{array}$ & 100 & $\mathrm{~V}$ & $\mathrm{~V}$ & $\mathrm{~N}$ & $\mathrm{~N}$ \\
\hline 4 & $\begin{array}{c}\text { Aspergillius } \\
\text { Niger(ATCC 16404) }\end{array}$ & 150 & $\mathrm{~V}$ & $\mathrm{~V}$ & $\mathrm{~N}$ & $\mathrm{~N}$ \\
\hline 5 & $\begin{array}{l}\text { Candida albicans (ATCC } \\
10231)\end{array}$ & 100 & $\mathrm{~V}$ & $\mathrm{~V}$ & $\mathrm{~N}$ & $\mathrm{~N}$ \\
\hline
\end{tabular}

$* \mathrm{CFU}=$ Colony formin

$* * \mathrm{~N}=$ No growth or bacteria was killed / inactivated

$\mathrm{MIC}=$ minimum inhibitory concentration expressed in ppm (parts per million in this contest)

Compound labeled as' 3j,' kills /inactivates the test organism Escherichia coli, (ATCC 10148), Staphylococcus aureus(NCTC 3750), Pseudomonas aeruginosa (Fisher'Immunotype IV), test fungai species used are Aspergillius Niger(ATCC 16404) and Candida albicans (ATCC 10231 in the concentration of 100 $\mathrm{ppm}$, In other words the compound $3 \mathrm{j}$ has shown the anti-bacterial/antifungal activities in the concentration of $100 \mathrm{ppm}$, against the above mentioned test bacterial/fungal species . whereas Standard reference sample ampicillin/fluconazole (MIC) at 100ppm in the same condition against Escherichia coli ,(ATCC 10148), and Staphylococcus aureus(NCTC 3750), but against Pseudomonas aeruginosa is150ppm. Standard reference sample fluconazole shows MIC at 100ppm against Candida albicans (ATCC 10231) but 150 ppm against Aspergillius Niger(ATCC 16404)

\section{Results And Discussion}

To study efficiency of two catalysts Potassium dihydrogenphosphate and phosphotugstic acid for Knoevenagel condensation, the reaction of hydroxy naphthaldehyde ,hydroxy benzaldehyde with diethylmalonate was selected as model. The results were summarised in Table-2\&3. Frist experiments focused on carry out these reaction in piperidine in microwave under normal condition.In the second stage all the reaction were carried out in presence of potassium dihydrogenphosphate catalyst with conventional heating and in modified microwave and compared their yield with first part.Under modified microwave heating offers a convenient environmentally friendly alternative to conventional reactions. Clearly, the reaction time by microwave heating has been reduced with higher yield than conventional heating ( $86 \%$ versus $65 \%$, )

Monitoring of the reactions and analysis can be accomplished by using standard methods .It is found that a 10 $\mathrm{mol} \%$ amount catalyst Potassium dihydrogen phosphate could effectively catalyze the reaction. With inclusion of $5 \mathrm{~mol} \%$ of catalysts the reaction took longer time. Using more amount catalysts $(20 \mathrm{~mol} \%)$ has less effect on the yield and time of the reaction ( $89 \%$ versus $75 \%$ ).

All the derivatives of the Coumarin obtained were characterized by Infra-red spectroscopy(FTIR) and Nuclear Magnetic spectroscopy (NMR) and further screened for anti bacterial,anti-fungal .the Table4-6)..

The formation of coumarins was evidenced by the absence of two peaks at $2880 \mathrm{~cm}^{-1}$ (Ar-CHO) and $3550 \mathrm{~cm}^{-1}(\mathrm{Ar}-\mathrm{OH})$ but the appearance of two prominent peaks due to $\mathrm{C}-\mathrm{O}-\mathrm{C}$ at $1275-1220 \mathrm{~cm}^{-1}$ and lactone $\mathrm{C}=$ Oat $1720-1700 \mathrm{~cm}^{-1}$, rest all the substituents peaks are shown as per literature .The detailed data is as shown in the Table -3

The proton nuclear magnetic spectral analysis $\left({ }^{1} \mathrm{HNMR}\right)$ of all the compounds showed signals corresponding to the multiplicity for different types of protons were consistent with assigned structure.

\section{Experimental Protocol}

All starting materials and reagents were commercially available and used without further purification. All chemical and solvents used were of A.R. grade. Further, remaining, pure reagents were purchased from S.D. chemicals. All the melting points were taken in an open capillary and are uncorrected.

I.R spectra of the synthesized compounds $3 \mathrm{~h}-\mathrm{j}$ were recorded were recorded on Bruker, Germany Model: 3000 Hyperion Microscope with Vertex 80 FTIR System.

The NMR spectra of all the synthesized compounds were recorded on Model: Mercury plus Make: Varian USA NMR AS $300 \mathrm{MHz}$ (strength 9.3 Tesla) Spectrophotometer at room temperature. 
For Microwave assisted reaction National 800 Watt model was used. Modified Microwave assisted reaction with solvent was carried out in LG MS.2349EB 900Watt model.

Anti-bacterial and anti-fungal activity of the all the compounds were carried out at Department of Bacteriology at Haffkine Institute for Training, Research \& testing Parel

\section{Conclusion}

* Highly practical procedure has been developed, using green chemistry principles for the synthesis of coumarin derivatives.

* A practical method for an efficient synthesis of product (h-j) using an inexpensive catalyst at ambient temperature has been described. High yields along with simple reaction condition auger well for the application of this strategy for the synthesis of derivative of coumarin.

* Mild reaction conditions, short reaction time, simple experimental work up cheapness of the reagents are the noteworthy advantages of this environment friendly protocol.

* This methodology offers significant improvements for the synthesis of derivatives of coumarins with regard to yield of products, simplicity in operation and green aspects by avoiding toxic conventional catalysts and solvents. Therefore owing the importance of Potassium dihydrogen phosphate a facile catalyst used for the green synthesis of new derivatives of coumarin .

* Thus the development of an efficient and versatile method to synthesis of coumarin derivatives is an active ongoing research and there is a scope further improvement towards milder reaction condition and yield.

* The compounds are found to possess good anti bacterial/anti fungal activity when compared with the standard.

\section{Acknowledgements}

Sincerely thank University Grants commission for approving and giving financial assistance for the minor research project undertaken for the Academic Year 2012-2014

\section{References}

[1]. Kennedy R. D. and Thomas R. D. Coumarins: Biology, Applications and mode of action John willey and sons, Chichester (1997).

[2]. Murray R.D.H., Mendez J., Brown S.A., "The Natural coumarins: Occurrence, Chemistry and Biochemisry"; Wiley and Sons: New York, (1982).

[3]. O'Kennedy R.O., Zhorenes R.D. ,Coumarins: Biology Applications and Mode of Action"; John Wiley and Sons: Chichester, (1997). (b) Yu, D. Xie M. L., Morris-Natschke S.L., Lee K.H., "Recent progress in the development of coumarin derivatives as potent anti-HIV agents"; Med. Res. Rev. 23, pp 322-345 (2003).

[4]. Zabradink M. ,"The Production and Application of Fluorescent Brrghtening Agent"; John Wiley and Sons: New York, (1992).

[5]. 5)(a) Raju B.B., Varadaraga T., "Spectroscopic studies of 7-diethylamino-3-styryl coumarins"; J. Photochem. ,Photobiol A. 85, pp 263-267 (1995). (b) Raju B.B., Varadarajan T. ,"Photophysical Properties and Energy Transfer Dye Laser Characteristics of 7Diethylamino-3-Heteroaryl Coumarin in Solution"; Laser chem. 16, pp 109-120 (1995).

[6]. Cravotto G., Nano G.M., Palmisano Tagliapietra G. S. ,"An asymmetric approach to coumarin anticoagulants via hetero-DielsAlder cycloaddition"; Tetrahedron: Asymmetry 12, pp 707-709 (2001

[7]. Sharma G.V.M, llangovan A, Narayan V. L and Gurjar M.K. Tetrahedron,59,(2003), 95.

[8]. Madhavan G.R., Balraju V, Mallesham B, Chakrabarti R and Lohray V.B., Bioorg .Med.chem .Lett, 13, (2003), 2547.

[9]. Raad I, Terreux R, Richomme P, Matera E L, Dumonter, Raynaud J and Guilet J .,Bioorg Med Chem 14, (2006), 6979.

[10]. Rao J M, Raju B C, Srinivas P V, Babu K S, Yadav J S, Raghavan K V and Nath C, Coumarins as AChE inhibitors , US and in Indian patent applied (2004).

[11]. Alexander M.V., Bhat P.R., Samant D.S. "Bismuth (III) nitrate pentahydrate — a mild and inexpensive reagent for synthesis of coumarins under mild conditions"; Tetrahedron Lett. 46, pp 6957-6959 (2005).

[12]. Watson T.B., Christiansen E.G. ,"Solid phase synthesis of substituted coumarin-3-carboxylic acids via the Knoevenagel condensation"; Tetrahedron Lett. 39, pp 6087-6090 (1998

[13]. Potdar M.K,. Mohile S.S., Salunkh M.M. "Coumarin syntheses via Pechmann condensation in Lewis acidic chloroaluminate ionic liquid"; Tetrahedron Lett. 42, pp $9285-9287$ (2001). (b) Khandekar A.C. ,Khadilka B.M,. "Pechmann Reaction in Chloroaluminate Ionic Liquid"; Synlett, pp152-154 (2002).

[14]. De La Hoz A., Moreno A. ,Vazquez E., "Use of Microwave Irradiation and Solid Acid Catalysts in an Enhanced and Environmentally Friendly Synthesis of Coumarin Derivatives "; Synlett, pp 608-610 (1999

[15]. Ander L., Microwaves in organic synthesis, John Wiley-VCH: New York, (2002). (b) Clark D.E., Sutton W.H., Lewis D.A., Eds. "Microwave-assisted reaction under solvent- free dry conditions." American Ceramic Society, Ceramic Transaction. 80, 357-361 (1997). 